\title{
Observations on the structure of Surtsey
}

\author{
JAMES G. MOORE ${ }^{1}$ AND MARIE D. JACKSON ${ }^{2}$
}

${ }^{1}$ U.S. Geological Survey, Menlo Park, California, U.S.A.

${ }^{2}$ Department of Geology and Geophysics, University of Utah, Salt Lake City, Utah, U.S.A.

\begin{abstract}
Comparison of investigations of the 1979 and 2017 cored boreholes coupled with continued observations of the dynamic surface of Surtsey has modified our concepts of the subsurface structure of the volcano. A geometrical analysis of the 2017 vertical and inclined cores indicates that near-surface layering dips westerly, indicating that the boreholes are located inside the Surtur crater. In subaerial deposits, as well as in deep deposits below sea level and below the pre-Surtsey seafloor, there are zones of porous tuff that contain abundant pyroclasts with narrow rims of fine ash. These features, typical of near-surface deposits, could have been carried down the vent by downslumping during fluctuating explosive activity. They support the hypothesis that a broad diatreme underlies the Surtur vent. No major intrusions were encountered in the 2017 drilling except for coherent basalt in deep sub-seafloor deposits below the center of Surtur crater. The 2017 borehole temperature measurements indicate that the peak temperature in the vertical boreholes was $124{ }^{\circ} \mathrm{C}$ at 105 meters below the surface (m.b.s.) and that in the inclined hole it was $127{ }^{\circ} \mathrm{C}$ at 115 m.b.s. immediately after drilling. These peak temperatures are 72 meters apart horizontally yet closely resemble each other in shape and magnitude, suggesting a broad heat source. In addition, measurements in the inclined hole from 200 to $290 \mathrm{~m}$.b.s. indicate a temperature of $60 \pm 2{ }^{\circ} \mathrm{C}$. This is apparently residual heat from the volcanic action that created the diatreme. These facts cast doubt on the previous concept that the heat anomaly in the 1979 borehole was due to a nearby intrusion. Instead they suggest that heat would have been conducted down from the 85-meter-thick hot lava shield within the Surtur crater into a warm diatreme substrate containing original volcanic heat. As the conducted heat moved down into the water-saturated substrate it would have elevated the temperature above the boiling point curve, baked out water, and created a vapor-dominated system below sea level. Eventually loss of heat by boiling and rise of steam caused the vapor-dominated system to retreat upward. The resulting steam rose and warmed the tephra adjacent to the lava shields where it produced broad areas of palagonitized tuff.
\end{abstract}

\section{INTRODUCTION}

A new era in Surtsey investigations began in 1979 when a $181 \mathrm{~m}$ deep borehole was drilled on the eastern flank of the Surtur vent (Fig. 1). The cored borehole was a cooperative venture between the Icelandic Natural History Museum, the Surtsey
Research Society, and the Geothermal Program of the U.S. Geological Survey (Jakobsson \& Moore 1982a). The Icelandic National Energy Authority conducted the drilling. This work led to a better understanding of the sub-surface structure and

This study is dedicated to Sveinn Jakobsson, the man who with his spirit and his boots has taken the pulse of Surtsey for five decades. 


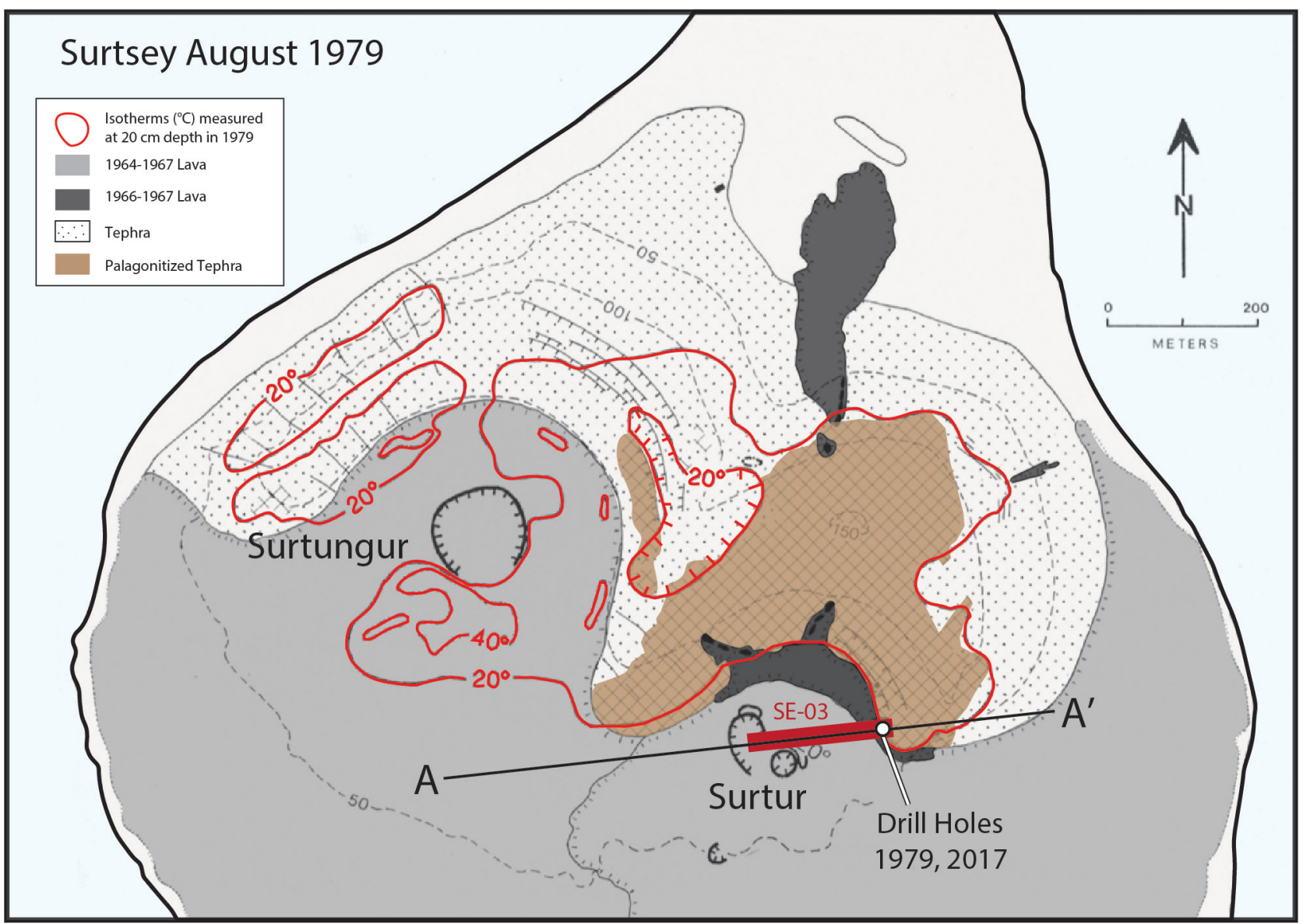

Figure1. Map of central Surtsey in 1979 showing lava of 1964-1967, in shades of gray. Tephra is dotted and the extent of palagonitized tephra in 1979 is shown in brown. Temperature of the 1979 hydrothermal area measured at depths of $20 \mathrm{~cm}$ is shown by red isotherms. Profile of Figure 10 is shown by the black line, with the red segment depicting the surface projection of the 2017 inclined borehole SE-03. Vertical boreholes SE-01, SE-02A and SE-02B occur at the east end of the red segment. After Jakobsson \& Moore (1982b) and Jackson et al. (2019a).

thermal history of the volcano and characterized the time-dependent growth of secondary hydrothermal minerals (Jakobsson \& Moore 1986). One result was the proposition that the Surtur and adjacent Surtungur vents are each underlain by a funnel-shaped diatreme (Moore 1985).

In 2017, 38 years after the completion of this first borehole (SE-01), three new cored boreholes were drilled (SE-02A, SE-02B, and SE-03) by the Surtsey Underwater volcanic System for Thermophiles, Alteration processes and INnovative Concretes (SUSTAIN) drilling project, sponsored by the International Continental Scientific Drilling Program (Jackson et al. 2019a, Weisenberger et al. 2019). Two new vertical boreholes (SE-02A, SE-02B) were placed within seven meters of the 1979 SE01 borehole and a third new borehole (SE-03) was drilled such that it plunged $55^{\circ} \mathrm{W}$ toward the Surtur crater and through the tuff deposits at the center of the postulated Surtur diatreme (Fig. 1). The holes were spudded in 170 meters east of the Surtur crater at an elevation of 58 meters. This work outlines some of the findings obtained from a comparative study of the two drilling projects.

\section{Sequence of events at the Surtur vent}

First observations of the Surtur vent occurred when explosions emerged above the sea surface and rapidly began building a tuff cone on November 14, 1963 (Thórarinsson 1965, 1967). The explosive activity continued until January 31, 1964, during which time continuous uprush explosions alternated with sea wave erosion of the crater rim allowing water to have access to the vent. A hypothesized diatreme is believed to have fed this 78-day explosive phase in late 1963 and early 1964 (Moore 1985). The eruption began when rising magma approached the ocean floor and heated interstitial water. When the 
boiling point was attained the generation of steam produced explosions that cleared the vent of rubble, tephra and water and built the edifice toward the sea surface. When the vent was open to the atmosphere continuous uprush explosions carried tephra to great heights and then deposited it within and around the crater. As the rim surrounding the vent was eroded by the sea, water poured down into the open vent, and landslides followed, cooling and quenching the explosions. This explosive cycle was repeated when debris in the diatreme was heated by new magma rising from below. The oscillation of material that was ejected from the vent and then returned to it by downfall, slumping, and landsliding can account for the deep occurrence of the vesicles in tuff deposits and lapilli with ash coatings observed in the 1979 core (Moore 1985). A variety of fine ash coatings on glass fragments occurs in submarine and sub-seafloor tuff deposits in the 2017 drill cores; these likely record diverse depositional processes (Jackson 2020).

Explosions ceased at Surtur on January 31, 1964 and then began at the new Surtungur vent 450 meters west-northwest (Fig. 1). These explosions occurred for 64 days covering the island and vicinity with air fall tephra. Eventually Surtungur grew well above the sea and sea incursion was suspended. Explosions ceased and effusive activity began April 4, 1964. Lava flows poured from Surtungur for more than two years. The flows built a lava shield, enlarged the island to the south and flowed east around the south side of Surtur until May 17, 1966. During this Surtungur effusive phase, the crater of Surtur remained largely empty. The crater of the Surtur vent is depicted on a map made from aerial photographs taken October 23, 1964 (Iceland Survey Department 1965) six months after the Surtungur lava flows had begun. It shows lava banked up against the south side of the Surtur crater with the crater floor now less than $20 \mathrm{~m}$ above sea level.

Effusive activity began at Surtur on August 19, 1966 and was active for nine months. A lava lake grew in the crater and lava fountains fed overflowing lava flows that built a lava shield above the original crater to 80 meters above sea level (Norrman 1970, Moore 1982). These flows overflowed to the south and east covering almost half of the area covered by the Surtungur lava flows and further enlarging the island. The eruption stopped on June 5, 1967.

In April 1968 elevated temperatures were first noticed in areas north of the Surtur lava shield that had been cool in July 1967 (Jakobsson 1978). By 1979 the surface temperature measurements of tephra at $20 \mathrm{~cm}$ depths exceeded $20^{\circ} \mathrm{C}$ in sizable areas north of both lava shields (Fig. 1) (Jakobsson \& Moore 1982b). Areas within these warm zones became lithified as the glassy tephra underwent palagonitization to form resistant tuff (Fig. 1).

\section{Sizes of volcanic clasts}

Surtsey tephra is poorly sorted with the largest clasts up to about one meter in size and the smallest comprising fine ash. The overall average grain size is about $0.5 \mathrm{~mm}$ with $60-70 \%$ in the coarse ash $(0.06-2$ $\mathrm{mm}$ ) fraction, and less than $0.5 \%$ in the block and bomb ( $>64 \mathrm{~mm}$ ) fraction (Sheridan 1972, Jakobsson et al. 2000).

Much of the tephra is made up of angular to sub-rounded lapilli of vesicular basalt, which is commonly grayish orange (10YR 7/4 Munsell color) sideromelane, and less abundant, dark gray opaque tachylite (N3) in hand sample. Olivine and plagioclase phenocrysts occur throughout. Glass lapilli commonly have rims of accretionary ash in the subaerial tuff cone and the borders of the fragments are variously altered and palagonitized (Lorenz 1974, Moore 1985). Narrow rims of fine ash also occur on altered glass pyroclasts in the submarine and subseafloor tuff deposits (Jackson 2020). Fragments of bombs are present as rounded or ribbon-like lava masses (McPhie et al. 2020). Xenocrysts of preSurtsey volcanic rock, sediment, and ice-rafted exotic rocks are present in the subaerial tephra and in the drill cores.

The 2017 drill core was photographed around its circumference in unrolled digital scans. The maximum size of clasts displayed in these scans was measured in each segment in the core trays, a sample size about one-meter long (Fig. 2). Clast sizes less than one centimeter were not recorded. This maximum clast size, as recorded in the core scans, is only one gauge of clast size because the HQ (6.35 $\mathrm{cm}$ diameter) and NQ ( $4.3 \mathrm{~cm}$ diameter) cores cannot encompass clasts of greater dimension. However, the measurements are useful for comparative purposes. Only a few unrolled digital scans were created for the 75-200 m.b.s. interval of the inclined SE-03 core.

In the SE-02A, SE-02B, and SE-03 cores most of the largest clasts fall in the range of $1-4 \mathrm{~cm}$ with perhaps $10 \%$ being larger (Fig. 2). Interestingly, this size range remains quite constant down to the bottom 


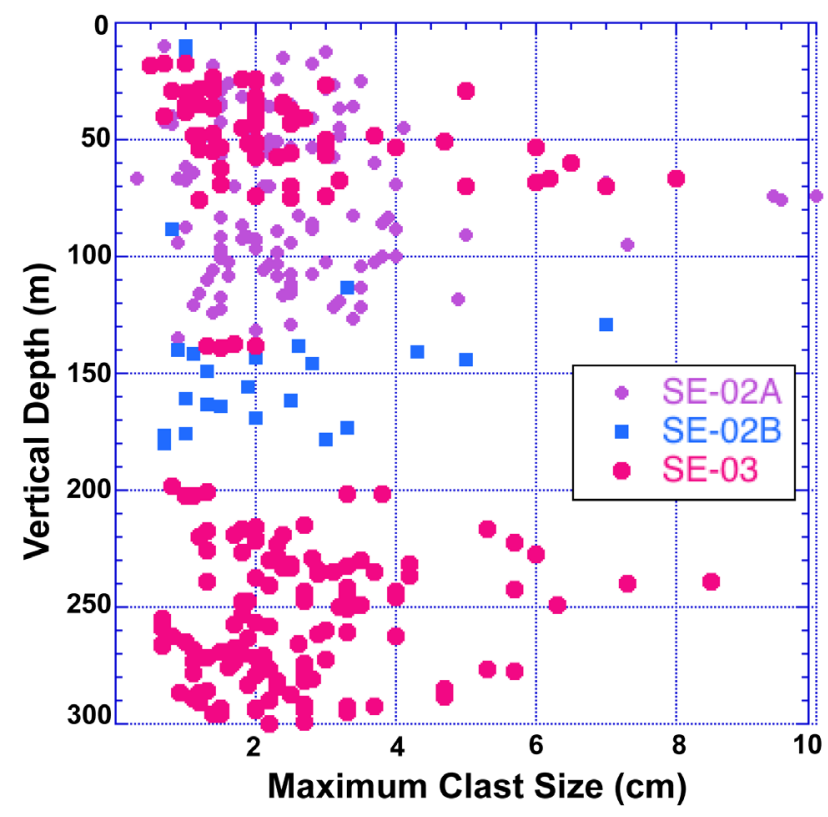

Figure 2. Maximum size of clasts in each approximately onemeter-long section of the three 2017 drill cores as measured in unrolled digital scans.

of the inclined borehole, SE-03, at a depth of 290 m.b.s. and horizontally $205 \mathrm{~m}$ west of the vertical holes. Such uniformity in the clast size distribution could imply extensive mixing from crater edge to center as might occur during the repetitive explosions in a diatreme.

\section{Vesicles in the tuff}

Vesicles that occur as open spaces in the ash matrix of the lapilli tuff are widespread in the Surtsey deposits. They are commonly $0.3-0.6 \mathrm{~mm}$ in diameter when spherical but exceed one $\mathrm{cm}$ when irregular in shape (Moore 1985). These vesicles are distinct from the much smaller vesicles $(<0.1 \mathrm{~mm})$, which are contained within glassy lapilli. The vesicles in tuff often show an amoeboid shape with small lobate peripheral protrusions that penetrate between lapilli. They may surround glass fragments with narrow rims of fine-ash (Jackson 2020). At deeper levels the vesicles are generally less abundant and take on a more jagged outline (Fig. 3).

The vesicles are well shown as open spaces in thin sections (Fig. 3) but cannot be readily identified in photographs and scans of the cores. Those measured through point counts of thin sections from the 1979 SE-01 core (see Moore, 1985, his figures 6 B, C, and D) commonly attain 25 volume $\%$ of the lapilli tuff near the surface but are less abundant in the deeper
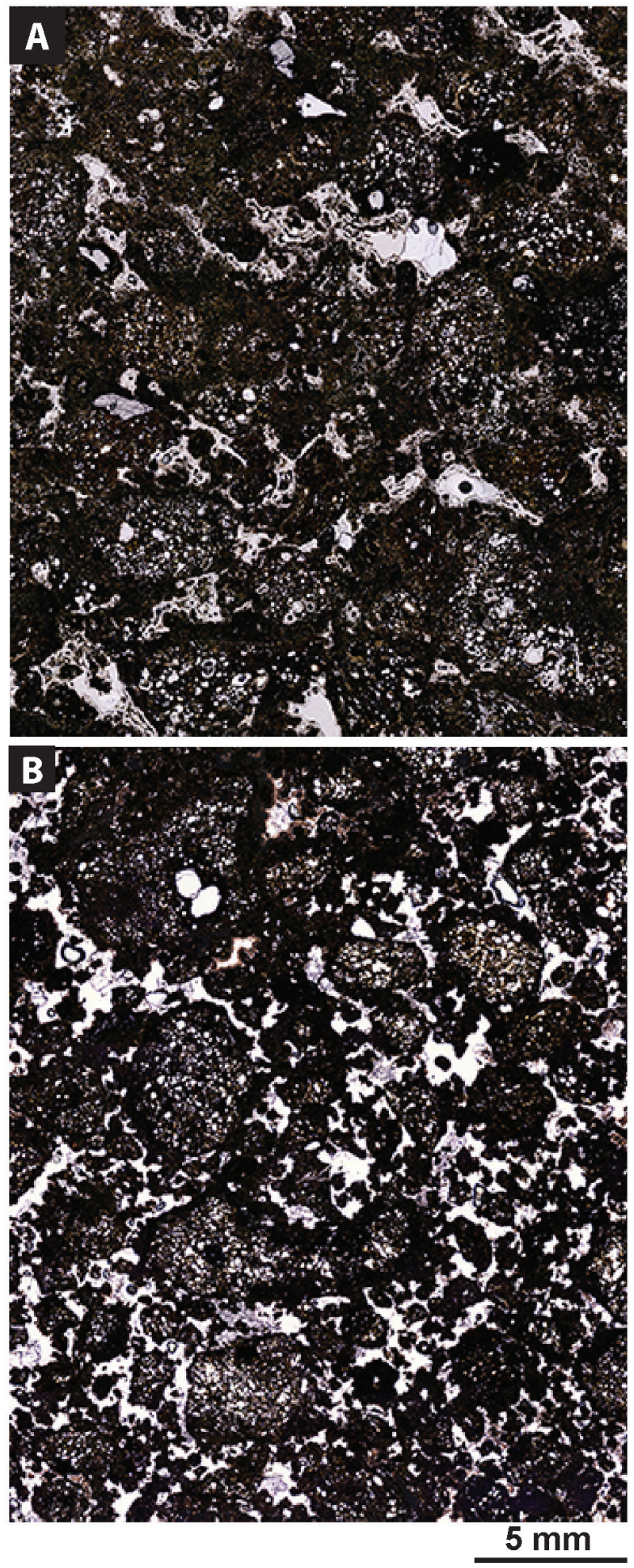

Figure 3. Scans of thin sections showing vesicles (white) in porous submarine and sub-seafloor basaltic lapilli tuff, plane polarized light. A) Borehole SE-02B, 77.9 m.b.s., Reference Sample 6; 12 volume \% vesicles. B) Borehole SE-03, 259 m measured depth, Reference Sample 24; 12 volume \% vesicles.

samples (Fig. 4). A similar pattern of decreasing vesicular space with depth occurs in the 2017 SE-02B core. Here, point counts of 32 reference sample thin 


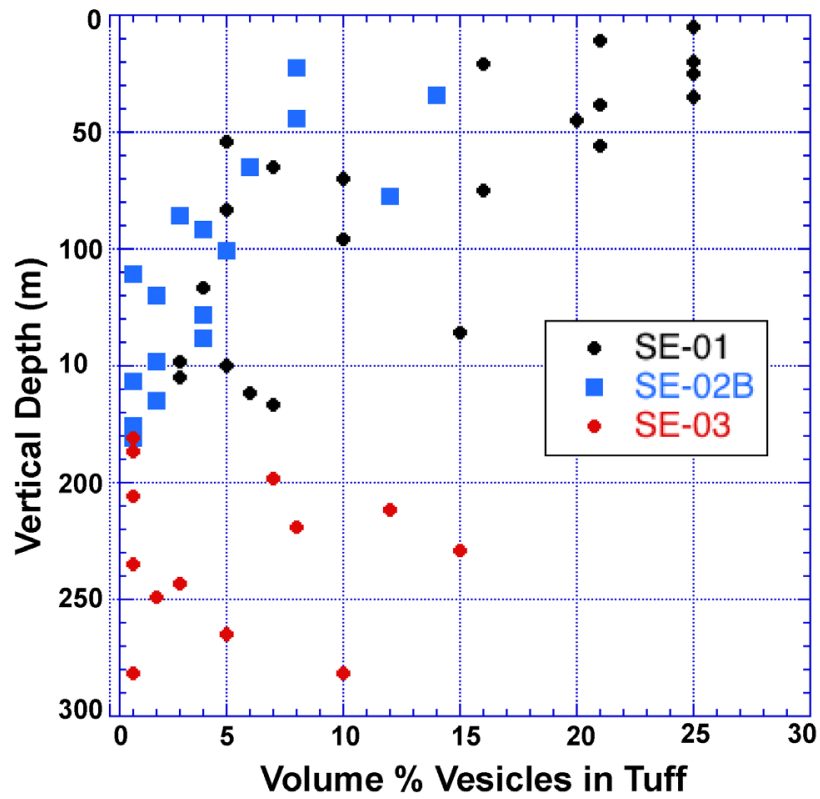

Figure 4. Volume \% vesicles in lapilli tuff as measured in thin sections of samples from boreholes SE-01, SE-02B, and SE-03.

sections were achieved through placing a transparent grid of 100 points on an enlarged high-resolution scan of the thin section. However, in the lower part of the SE-03 inclined core below $200 \mathrm{~m}, 13$ samples of lapilli tuff show a somewhat higher average volume of vesicles. Seven samples contain 3 or fewer volume percent vesicles and the remaining 6 contain 5-15 volume \% vesicles (Fig. 4). The more porous deposits have lower bulk density and higher water absorption than more compact deposits (Jackson 2020).

Tuff vesicles described at phreatomagmatic centers (Lorenz 1974a, 1974b) commonly form near the surface where air is trapped in water-saturated fine ash, or mud. It is unlikely that the vesicles could persist in lapilli or ash that has fallen on the sea surface and then descended to the sea floor. Hence the presence of the vesicles down to the lower sections of the cored boreholes could suggest that tephra which entrapped air or other gases near the surface was carried down by slumping and landslides into the sub-seafloor deposits (Moore 1985).

\section{Dip of layering}

Measurement of the dip of layering on the digital scans of the 2017 cores utilizes the expression of each planar layer boundary as a sine curve on the unrolled image (Fig. 5). As the bed dip steepens the amplitude of the sine curve increases. The dip is defined as

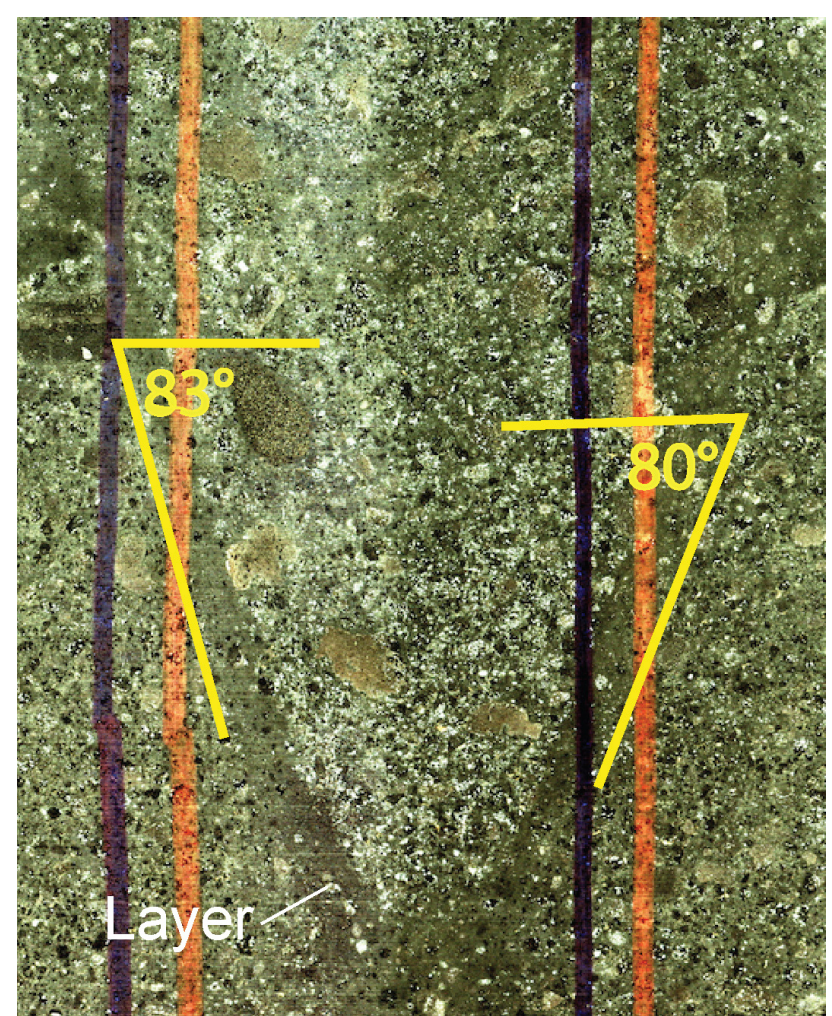

Figure 5. Unrolled digital scan (20 cm across) of the 2017 borehole SE-2A core at 38.3 m.b.s. A planar dipping dark ash layer is expressed as a sine curve. The dip is the angle between each of the steep parts of the curve and a plane normal to the core axis. The average dip is $71^{\circ}$.

the angle between the normal to the axis of the core and the steepest part of the curve (Fig. 5). The dip is measured on both sides of the sine curve crest, and the average is recorded.

In the SE-01 core the dip of planar surfaces, as bedding, slump and shear planes, in the upper $50 \mathrm{~m}$ of the borehole is generally $10^{\circ}-45^{\circ}$, averaging $30^{\circ}$ (Moore, 1985). From 50-100 m.b.s. the dip increases generally to $40^{\circ}-60^{\circ}$ and below this the dips broaden in value generally from $15^{\circ}-80^{\circ}$. The dip of layering in the upper part of borehole SE-2A shallower than 100 m.b.s. is generally $20^{\circ}-50^{\circ}$, averaging $30^{\circ}$. Below this depth the dip broadens, generally between $10^{\circ}$ and $70^{\circ}$ (Fig. 6).

The apparent dip of planar surfaces in inclined borehole SE-03 is largely measurable only above 75 m.b.s. and from 230-290 m.b.s. Only a few digital unrolled scans of the core were made at intermediary depths, for example, at about $140 \mathrm{~m}$. Above 50 m.b.s., the apparent dips are rather tightly clustered between $60^{\circ}-80^{\circ}$, averaging $70^{\circ}$ (Fig. 6). In the lower interval the apparent dips are largely between $40^{\circ}-80^{\circ}$. 


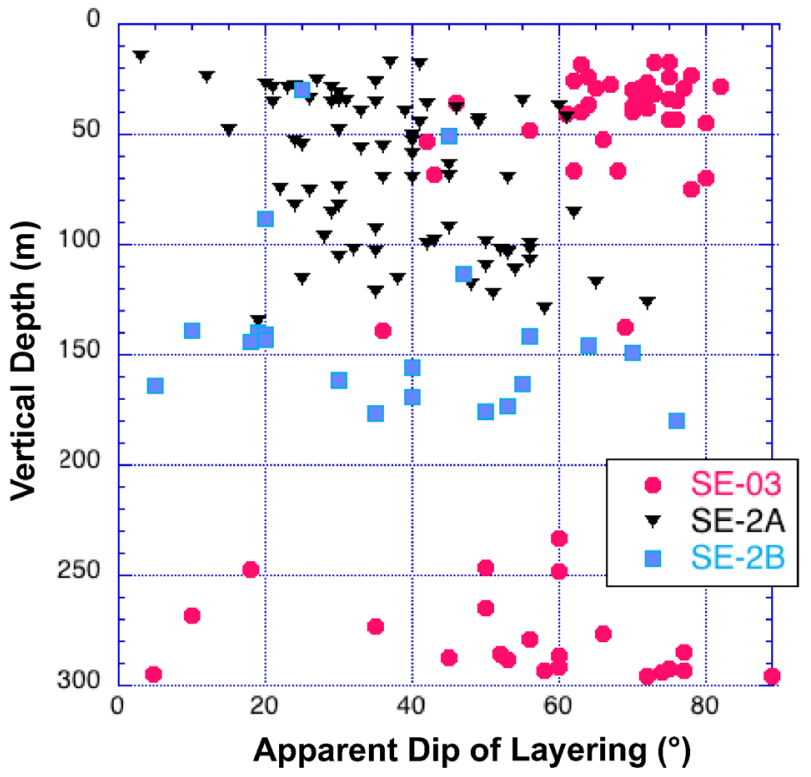

Figure 6. Dip of layering in boreholes SE-02A, SE-02B, and SE03 as measured from unrolled digital scans.

Since the azimuth of the core was not fixed during drilling, the direction of the dip of planar surfaces is not defined in any of the 1979 or 2017 cores. However, there is a relation of the measured apparent dip in the inclined SE-03 core with the equivalent true dip if it is assumed that the layering dips either west or east, along the azimuth of the inclined borehole (azimuth $264^{\circ}$, plunge $55^{\circ} \mathrm{W}$ ) (Fig. 7). This assumption is reasonable because the axis of the borehole is radial to the volcanic vent (Fig. 1) and it is considered likely that the layering will be dipping toward the vent (inner crater wall) or away from the vent (outer crater slope).

The relation of the apparent dip to the true dip relative to the horizontal in the inclined SE-03 core is such that steep apparent dips are more common in westerly true dips, and gentle apparent dips are more common in easterly true dips (Fig. 7). If the layering is at right angles to the inclined core (that is, $0^{\circ}$ apparent dip) then the true dip will be $35^{\circ} \mathrm{E}$. If the layering has an apparent dip of $10^{\circ}$ then the true dip may dip either $25^{\circ} \mathrm{E}$ or $45^{\circ} \mathrm{E}$ relative to the horizontal. If the layering has an apparent dip of $90^{\circ}$ (that is, parallel to the axis of the inclined core) then the true dip is $55^{\circ} \mathrm{W}$. Hence, true dip can be assessed by comparison of measurements of apparent dip in the inclined SE-03 core and true dip in the vertical cores provided the boreholes are close together.

The dip of layering in the upper part of vertical borehole SE-02A above 50 m.b.s. is generally $20^{\circ}-50^{\circ}$, averaging $35^{\circ}$ (Fig. 6). In contrast, the apparent dip in the upper part of inclined borehole SE- 03 is $60^{\circ}-80^{\circ}$, averaging $70^{\circ}$ (Fig. 6). The $70^{\circ}$ apparent dip is equivalent to a true dip of either $35^{\circ}$ $\mathrm{W}$ or $85^{\circ} \mathrm{W}$ relative to the horizontal (Fig. 7). The correspondence of the $35^{\circ} \mathrm{W}$ true dips in the SE03 core with the $35^{\circ}$ dips in the three vertical holes establishes that the layering above 50 m.b.s. in the cores dips west at an inclination averaging about $35^{\circ}$. Therefore, the boreholes are all located in the inner wall of the Surtur crater and not on the outer volcano slope. The dip of layers deeper in the boreholes cannot be quantified because the horizontal distance between vertical boreholes and the inclined borehole increases to about $200 \mathrm{~m}$. It is evident, however, that the dispersion of dips increases with depth. The structures deeper in the subsurface apparently become more complex.

On the western side of Surtsey the sea has eroded several hundred meters into the Surtungur vent complex (Fig. 8). This has produced a cliff $140 \mathrm{~m}$ high that exposes a rhythmically-bedded section of tuff that dips east (Jakobsson et al. 2013). The dip of layering becomes steeper downward attaining approximately $45^{\circ}$ near the bottom of the cliff at sea level. It therefore resembles the inner-dipping, downward-

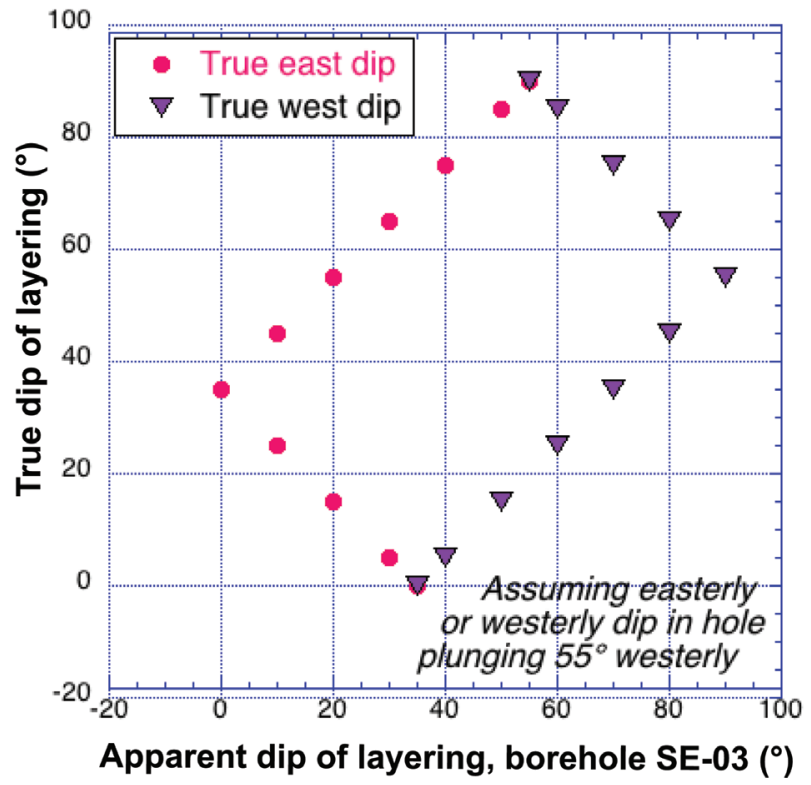

Figure 7. Relation between the apparent dip of bedding in the inclined borehole SE- 03 that plunges $55^{\circ}$ westerly and the true dip, assuming that the dip is either easterly or westerly. Note that gentle apparent dips in the drill core generally indicate true easterly dips and steep apparent dips generally indicate true westerly dips. 


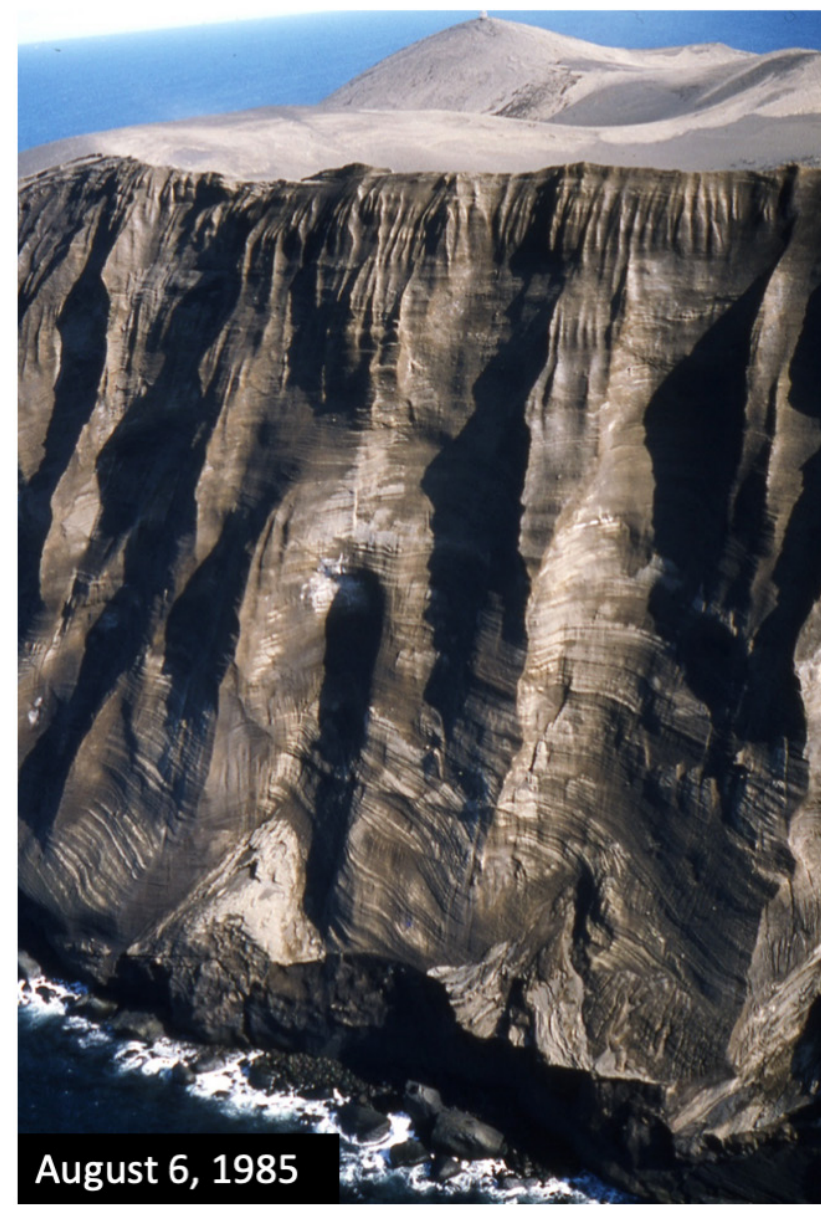

Figure 8. Looking east to the $140 \mathrm{~m}$-high seacliff on the west side of Surtsey. The east-dipping tuff layers apparently belong to the west side of the postulated diatreme beneath the Surtungur vent complex. Note that the dip of layering becomes steeper downward. After Jakobsson et al. (2013).

steepening layers that are a hallmark of diatremes (Lorenz 1986, his fig. 1). This cliff exposure of the postulated Surtungur diatreme (Moore 1985) is $400 \mathrm{~m}$ from the center of the vent suggesting that the radius of the Surtungur structure is at least that dimension at sea level. In comparison the radius of the postulated Surtur diatreme is approximately $250 \mathrm{~m}$ at sea level.

The Surtungur tuff sequence as exposed in the cliff consists of alternating light and dark beds with each couplet averaging about $1.5 \mathrm{~m}$ thick. The beds were perhaps alternately deposited during (1) a ventclearing process when water, rubble, and tephra was expelled from the vent by steam explosions (light layer), and (2) a continuous-uprush magmatic explosion process when incandescent tephra was erupted to a great height and fell back into the crater (dark layer).

\section{Lava shields}

During the nine and a half months of the Surtur effusive eruption beginning August 19, 1966 a lava shield was built within the Surtur tephra crater. A similar, though somewhat larger, shield grew earlier in the Surtungur crater for 19 months from April 4, 1964 to October 17, 1965. These lava shields consist of a central cone surrounded at a distance of 350-450 $\mathrm{m}$ by a lower gradient lava apron. The Surtur cone is $85 \mathrm{~m}$ above sea level and the Surtungur cone, $110 \mathrm{~m}$ above sea level. Slopes of the Surtur cone average $6^{\circ}-7^{\circ}$ and its outer lava slopes average $2^{\circ}-5^{\circ}$ (Thórdarson 2000).

Leveling surveys showed that the center of the island subsided as much as $30 \mathrm{~cm}$ relative to the east and west sides from 1967 to 1968 in the year after the eruption stopped (Tryggvason 1972). Subsidence continued at a reduced rate through 1970 and beyond (Moore 1982). Hence, the lava shields were actively subsiding at the end of volcanic activity, perhaps because the weight and heat of the newly grown shields compressed the loose tephra on which they rest. Subsidence was possibly more rapid earlier when the lava shields were actively growing. The amount of thickening of the lava shields and lowering of their bases below sea level is unknown but is possibly several meters or more.

The initially hot lava shields may be important heat sources for the early hydrothermal system of the volcano. During the months of their eruption, an active lava lake occurred within the craters, lava fountains played, and lava overflowed the crater rims (Thórarinsson 1965). The flows stacked one upon another with little time to cool between overflows. Some flows were fed through tubes from the central lake to the shield flanks. The measured temperature of molten lava during the Surtungur effusive phase was 1138-1182 ${ }^{\circ} \mathrm{C}$ (Sigurgeirsson 1965), and magmatic temperatures at the Surtur shield were similar. The 80-m-thick lava shield should take decades to cool. Moreover, the substrate beneath the Surtur shield retained a part of its original volcanic heat. The lower 90 meters of the SE-03 inclined borehole was a uniform $60{ }^{\circ} \mathrm{C}$ in 2017 immediately after drilling (Fig. 9) about one-half the peak temperature at about 115 m.b.s.

The cooling of ponded Hawaiian basalts has been studied by drilling programs that are useful in assessing the cooling of the Surtsey lava shields. Recent Hawaiian lava lakes overlay non-saturated 


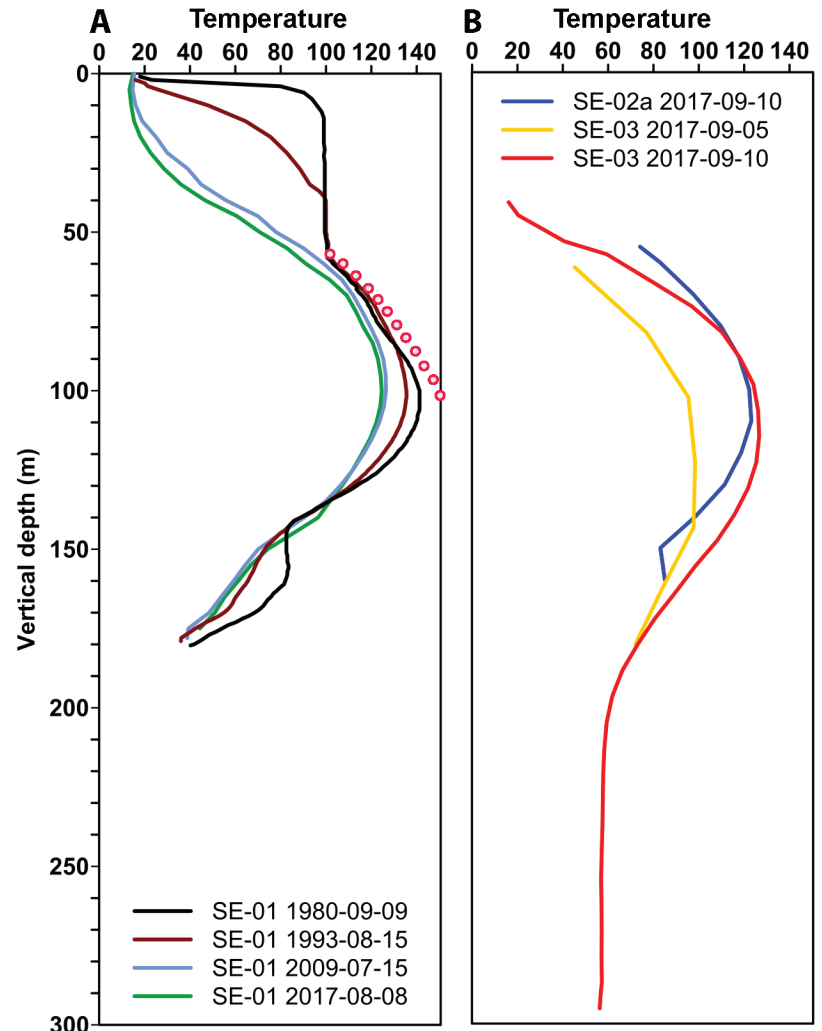

Figure 9. Temperatures measured in the Surtsey boreholes relative to vertical depth. A) 1979 SE-01 borehole temperatures measured in 1980, 1993, 2009, and 2017; red dotted line is boiling point curve. B) Borehole temperatures, SE-02a and SE-03 measured in 2017. After Jackson et al. (2019a).

substrates whereas the Surtsey lava shields overlay water saturated substrates. However, precipitation is three times greater in Hawaii and perched water tables are common.

The 1963 Alai lava lake (15-m-thick and $300 \mathrm{~m}$ in diameter) became solid about one year after eruption. Two years after the eruption the temperature in the substrate $8 \mathrm{~m}$ beneath the lava lake was estimated to be $250{ }^{\circ} \mathrm{C}$ (Peck et al. 1977). The 1959 Kilauea Iki lava lake (130 m thick and $750 \mathrm{~m}$ by $1350 \mathrm{~m}$ in areal extent) became solid about 20 years after eruption. Magnetic measurements indicate that it will cool below the Curie Point $\left(540{ }^{\circ} \mathrm{C}\right.$ ) in 2037 (Gailler \& Kauahikaua 2017).

Magnetic measurements on the southern margin of the Surtungur lava shield showed a marked increase in magnetization between 1969 and 1970. This increase indicates that large amounts of the basalt shield cooled below the Curie Point (500-580 ${ }^{\circ} \mathrm{C}$ ) and became magnetized (Sigurgeirsson 1974). Hence, 4 to 5 years after eruption the temperatures in the lava comprising the Surtungur lava shield had decreased to below $580{ }^{\circ} \mathrm{C}$.

In 1987, temperature measurements in fissures on the top of the Surtungur lava shield yielded values up to $300{ }^{\circ} \mathrm{C}$ (Jakobsson \& Moore 2000, their fig. 4). This near-surface high temperature (22 years after the end of lava effusion) implies that the core of the shield was at a still higher temperature,

\section{Borehole temperature measurements}

In 1980, the temperature profile in the 1979 SE-01 borehole showed a positive bulge, or anomaly, at 105 m.b.s. peaking at $141{ }^{\circ} \mathrm{C}$. Traced upward from the top of this bulge the temperature profile is slightly below and nearly parallel to the boiling point curve (Fig. 9). At the crest of the bulge the temperature is about $10{ }^{\circ} \mathrm{C}$ below the curve. Near sea level $(58$ m.b.s.) the profile joined the boiling point curve (Jakobsson \& Moore 1982b) (Fig. 9). In 1979 measurements of the depth of the water level in the borehole were difficult to establish because the water surface was boiling (Moore 1982). In 1993 (26 years after the eruption ceased) the temperature at sea level was still at the boiling point curve (Fig. 9). Measurements after 1993 show that the borehole temperature was cooler than the boiling point curve.

Since 1979 the maximum temperature in the bulge has decreased. It was $135^{\circ} \mathrm{C}$ in $1993,126{ }^{\circ} \mathrm{C}$ in 2009, and $124^{\circ} \mathrm{C}$ in 2017 (Jackson et al. 2019a). Even in 2017 the upper limb of the temperature profile mimicked the boiling point curve but was 20 $-30{ }^{\circ} \mathrm{C}$ cooler (Fig. 9). On September 10, 2017, 24 days after drilling ceased on August 17, the shape of the temperature profile in the SE-02A borehole was very similar to that measured August 8, 2017 in the 1979 SE-01 borehole located $7 \mathrm{~m}$ to the east (Fig. 9).

The drilling of the inclined SE-03 borehole was completed September 4, 2017. The temperature measured the next day already showed the temperature bulge despite the cooling induced by drilling fluids. Five days later on September 10, the temperature anomaly in borehole SE-03 had increased to a peak of $127^{\circ} \mathrm{C}$ at 115 m.b.s., slightly deeper and hotter than that in the SE-02A borehole (Fig. 9). The temperature presumably continued to rise slightly as the borehole attained equilibrium. It is clear, however, that the general shape and depth of the temperature anomaly in the inclined borehole is remarkably similar to that of the vertical boreholes even though the site of the temperature bulge is 72 
$\mathrm{m}$ to the west. This suggests that the heat source, or sources, are laterally large. The slightly higher temperature of the anomaly crest in the inclined hole suggests that the heat source(s) may be more pronounced toward the west.

The temperature measured in 1980 at the bottom of the SE-01 borehole at 180 m.b.s. was $40{ }^{\circ} \mathrm{C}$ (Jakobsson \& Moore 1982, their figure 5). By 2017 it was only a few degrees cooler (Fig. 9). In contrast, the 2017 temperature in the inclined SE-03 borehole at $180 \mathrm{~m}$ vertical depth was $75^{\circ} \mathrm{C}$. At this level $125 \mathrm{~m}$ to the west, the interior deposits were $35^{\circ} \mathrm{C}$ warmer than the exterior deposits.

Proceeding downward in the SE-03 inclined borehole, the temperature decreases to $60 \pm 2{ }^{\circ} \mathrm{C}$ and remains constant from 200 m.b.s. to 290 m.b.s., near the center of the vent (Fig. 9). This suggests that the sub-seafloor lapilli tuff has retained residual heat from the series of phreatomagmatic explosions that created the deposits. Previously, this lower zone could have been hotter but in the 52 years since it was deposited in the earliest Surtsey activity it has probably cooled. This residual heat may have played a role in enhancing the temperature of the peak anomalies above. Future monitoring of temperature in the lower part of borehole SE-03 could determine the rate of cooling of this sector of the Surtur diatreme. Back plotting of this rate may help in an estimate of the initial temperatures.

The subaerial tephra deposits north of the Surtur vent began warming in April,1968. In September 1969 , temperatures of $48-84{ }^{\circ} \mathrm{C}$ were measured at approximate depths of $5 \mathrm{~cm}$ in the hottest areas where steam escaped to the surface (Jakobsson 1972). In August 1979, many measurements of ground temperature were made with probes placed at a uniform depth of $20 \mathrm{~cm}$ in the tephra deposits. These show zones hotter than $20^{\circ} \mathrm{C}$ spanning broad areas adjacent to the Surtur and Surtungur vents (Fig. 1). Areas of palagonitized tuff generally occur within the $20{ }^{\circ} \mathrm{C}$ isotherms (Jakobsson \& Moore 1982b). In subsequent years these palagonitized areas grew larger. However, much of this expansion was due to wind erosion of unpalagonitized tephra from atop palagonitized tuff (Jakobsson et al., 2000). In 2002-2008 a hot spring appeared on the northwestern shore north of the Surtungur vent. The maximum water temperature measured was 82 ${ }^{\circ} \mathrm{C}$ (Ólafsson \& Jakobsson 2009, their figs. 1 and $5)$.

\section{Surtur hydrothermal system}

Previously the measured heat anomaly within the 1979 SE-01 borehole was believed to have been caused by the intrusion of nearby feeder dikes (Jakobsson \& Moore 1986). This concept is now considered unlikely since the small dike cluster encountered in the SE-01 borehole (Jakobsson \& Moore 1982) is too small to produce the elevated temperatures (Axelsson et al., 1982) and also because no major intrusions were encountered in the 2017 drilling except near the bottom of the inclined SE-03 borehole.

The revised interpretation considered here points to both the residual heat within the diatreme (Fig. 9) and the overlying hot Surtur lava shield as possible heat sources (Fig. 10). These could account for the similarity in shape and magnitude of the 2017 high temperature anomalies in both the vertical and inclined boreholes even though they are $72 \mathrm{~m}$ apart horizontally (Figs. 9, 10). As the lava shield cools heat is conducted from its upper zones to the atmosphere, enhanced by wind and precipitation. The heat in its lower zones could be conducted downward where it would be dissipated in three ways: (1) by conduction of heat into the previously heated watersaturated tephra and tuff below sea level, (2) by the phase change that occurs when interstitial water boils in the substrate, and (3) by upward convection of rising steam.

After the growth of each lava shield heating of the substrate could have occurred by conduction of heat downward from the hot lava. This could have rapidly heated the warm substrate above the boiling point and created a vapor-dominated system that grew downward as it heated. The greatest depth that it attained would have been at the depth of the maximum heat anomalies (at about 105 m.b.s. in the vertical boreholes and 115 m.b.s. in the inclined borehole).

Eventually, as interstitial water boiled the downward conducted heat was offset by the loss of the heat of vaporization of the interstitial water and by the convection of steam upward. The vapordominated system then began to shrink upward as the temperature fell below the boiling point curve at depth. At the time of the 1979 drilling (13 years after eruptions terminated) the system had shrunk back to a thin zone below sea level where water was still actively boiling in the borehole and the steam was able to heat the borehole to $100{ }^{\circ} \mathrm{C}$ up to 50 meters above sea level (Jakobsson \& Moore 1982, Fig. 9). 


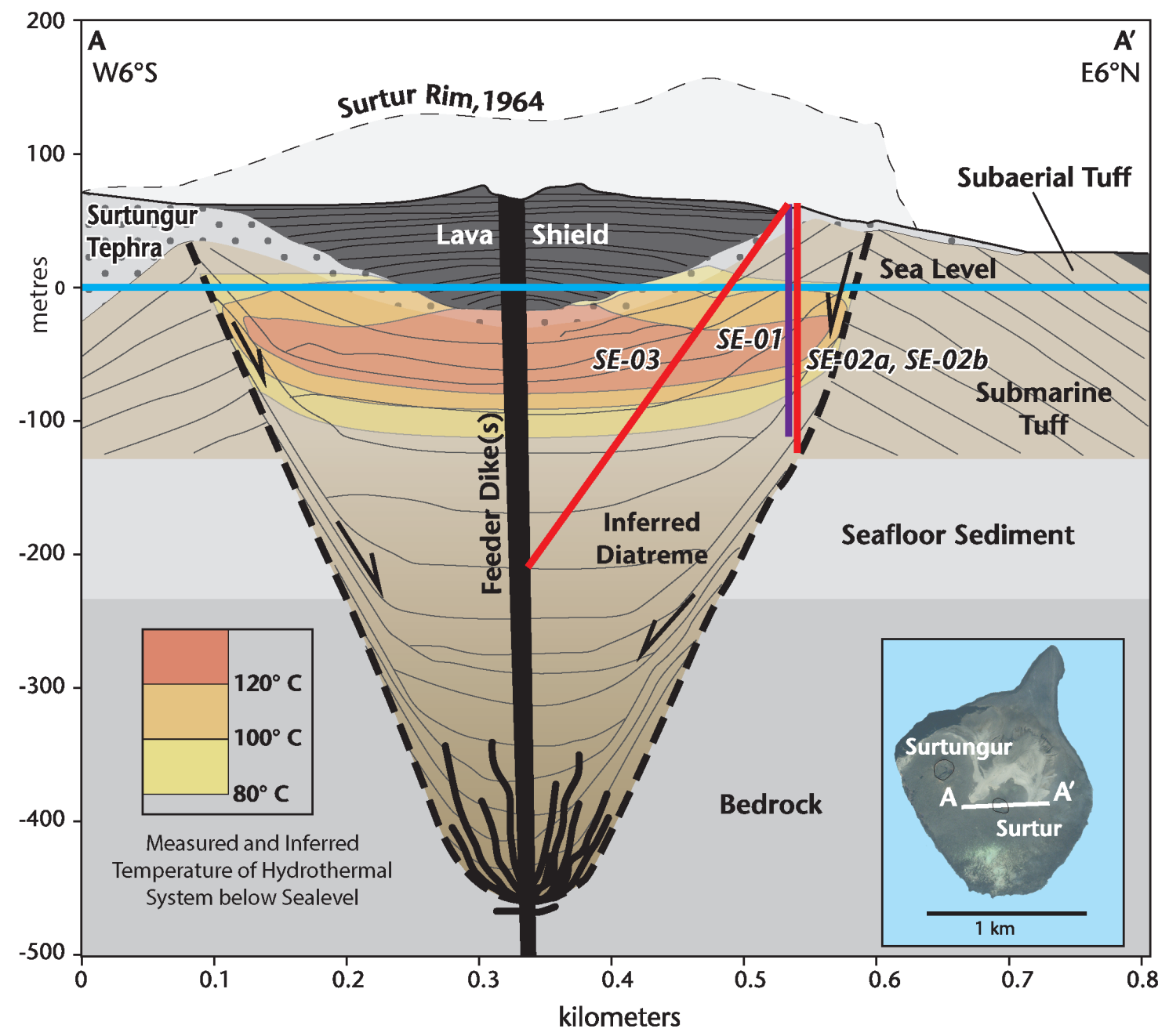

Figure 10. Structure of the Surtur vent and hypothesized diatreme as deduced from eruptive history and cored boreholes (red). Tephra from Surtungur (dotted pattern) and from Surtur (undotted), and the lava shield (dark gray). Conjectural temperatures in the 2017 hydrothermal system beyond those measured in boreholes are shown only below sea level.

By 1993 (26 years after eruptions terminated) the peak of the temperature profile had cooled slightly but the profile still joined the boiling point curve near sea level, indicating the vapor-dominated system still existed at this site. At this time rising steam was able to heat the borehole to $100{ }^{\circ} \mathrm{C}$ up to $20 \mathrm{~m}$ above sea level (Fig. 9). The vapor-dominated system was possibly hotter and deeper to the west.

Somewhat after 1993, the vapor-dominated systems disappeared in the 1979 SE-01 borehole and the copious steam that was previously detected at the surface abated. Later temperature measurements in 2009 and 2017 were below the boiling point curve (Fig. 9). Cooling was retarded because the formation of steam and the movement of steam ceased. However, even in 2017 the close parallelism of the upper limb of the temperature profiles with the boiling point curve immediately after drilling points to previously hotter profiles constrained by the curve. The hydrothermal zone under the Surtur lava shield and beneath sea level may be symmetrical as depicted in Figure 10. However, the zone may be deeper toward the vent where there is a thicker pile of lava flows. The western part of the hydrothermal zone may also be enhanced by heat from the neighboring Surtungur lava shield contributing to the overall heating of the substrate. The temperature of the Surtungur hydrothermal system is possibly higher than that of the Surtur system because the lava shield is thicker and because the hypothesized diatreme grew upward through the edge of the warm Surtur submarine tephra deposits rather than entirely through seawater as was the case with Surtur. The hot spring on the northwest coast of Surtsey apparently taps hot water from the Surtungur hydrothermal system. 
During the life of the vapor-dominated system steam moved upward to the subaerial deposits on the volcano where it was diverted around the hot lava shield and heated the tephra to the north of the Surtur shield thereby producing palagonitized tuff (Fig. 1). The area of palagonitization first noticed in 1969 (Jakobsson 1972) grew until it encompassed much of the tephra deposits of Surtur and Surtungur by 2006 (Ólafsson \& Jakobsson 2009, their fig. 1).

\section{CONCLUSIONS}

The 2017 SUSTAIN drilling project provides new constraints on the structure of Surtsey volcano and supports the hypothesis that both the Surtur and Surtungur vents are underlain by broad diatremes. Fragment size and sorting in samples from the inclined SE- 03 borehole that reaches the approximate center of the Surtur vent are similar to those in the vertical boreholes near the east edge of the Surtur crater. Zones of porous tuff with vesicular fabrics and narrow rims of fine ash on glassy pyroclasts occur in lapilli tuff deposits deep below water level in the vertical boreholes and below the pre-eruption sea floor in the inclined borehole (Fig. 3). These features could have formed in near-surface deposits produced by explosive eruptions. That they occur at depth supports the notion of diatreme growth by deep explosions that repeatedly cleared the vent and then were followed by down-slumping that partly filled the vent with re-mobilized surficial tephra. Likewise, the similarity in clast size in the cores traversing the Surtur deposits horizontally and vertically could indicate mixing induced by a diatreme explosion process (Fig. 4).

Analysis of the orientation of layering in the vertical and inclined Surtur cores indicates that the layering dips systematically west in the lapilli tuff deposits above 50 m.b.s. The westward dip of the layering supports the concept of a wide diatreme with a rim east of the vertical boreholes (Fig. 10). Deeper submarine and sub-seafloor tuff deposits show more complex orientations of layering, perhaps related to structures produced by explosions and subsidence. A 140-meter-high sea cliff on the west side of Surtsey exposes a thick sequence of east-dipping tuff layers that increase in dip downward. They apparently belong to the west side of the crater that merges downward into the postulated diatreme underlying the Surtungur lava shield.
The general absence of basaltic intrusions in the 2017 boreholes except in the lowest part of the inclined SE-03 borehole near the central axis of the Surtur vent casts doubt on the supposition that the heat anomaly measured in the 1979 SE-01 borehole results from nearby intrusions (Jakobsson \& Moore 1986). Borehole measurements in 2017 revealed a maximum temperature anomaly in the vertical borehole SE-01 of $124{ }^{\circ} \mathrm{C}$ at 105 m.b.s. This anomaly closely duplicates the maximum temperature anomaly in the inclined borehole SE03, which is $127^{\circ} \mathrm{C}$ at $115 \mathrm{~m}$.b.s. The similarity of these anomalies that are 72 meters apart horizontally suggests that their temperature source(s) were laterally broad.

The temperature measured in 2017 in the lower part of the inclined borehole SE-03 at 200-290 m.b.s. was remarkably uniform at $60 \pm 2^{\circ}$. This warm temperature is believed to reflect residual heat from the hydromagmatic explosive eruption that created the postulated diatreme that led to the birth of Surtsey island. Such heat, no doubt, has contributed to the elevated temperatures in the hydrothermal system.

Another source of heat in the hydrothermal system may be the 85 -meter-thick lava shield that grew in the Surtur crater in 1966-1967. Downward conduction of heat from the lava could have heated the water-saturated substrate above the boiling point creating a downward migrating vapor-dominated system. The greatest depth that it attained is recorded by the sites of the maximum heat anomalies (at about 105 m.b.s. in the vertical boreholes and 115 m.b.s. in the inclined borehole). As downward conducted heat waned the generation of steam eventually began to cool the system at depth by removing the heat of vaporization of the interstitial water and by convection of steam upward. As the temperature fell below the boiling point curve, the vapor dominated systems shrank. In 1979 the system was limited to a narrow zone somewhat below sea level where water was actively boiling in the SE-01 borehole. After 1993 the substrate steadily cooled; temperatures fell below the boiling point curve (Fig. 9) and the vapor-dominated zone disappeared. When the vapor-dominated system was most active steam from boiling interstitial water rose above sea level, heated the surrounding glassy tephra, and increased the rates of palagonitization of the lapilli tuff. 


\section{ACKNOWLEDGEMENTS}

Funding for 2017 drilling was provided by the International Continental Scientific Drilling Program (ICDP) through a grant to the SUSTAIN project; a grant of excellence from the Icelandic Research Fund, ICF-RANNÍS; the Bergen Research Foundation and K.G. Jebsen Centre for Deep Sea Research at the University of Bergen, Norway; the German Research Foundation (DFG), and DiSTAR, Federico II, University of Naples, Federico II, Italy. The University of Utah, USA, and the two Icelandic power companies Reykjavík Energy and Landsvirkjun contributed additional funds. The logistical support organized by Magnús T. Gudmundsson and provided by the Icelandic Coast Guard was instrumental in carrying out the drilling operation. The DOSECC drilling team was led by Beau Marshall with drillers Steve Cole, Justin Blouin, A. J. Vecchiarelli, Matthew Lyon, and Michael Vinson. The 1979 drilling team was led by Sigidur Sveinsson with drillers Jon Stefansson, Helgi Arsaelsson, Eirikur Stigsson, and Gudmundur Sigurdsson. Kristján Jónasson maintains the Surtsey drill core archive at the Iceland Institute of Natural History. Bronze Black drafted figures 1 and 10. We thank Michael Clynne, Kristján Jónasson, and J. Michael Rhodes for reviews which have substantially improved the manuscript.

\section{REFERENCES}

Axelsson, G., V. Stefánsson, G. Gudmundsson \& B. Steingrímsson, 1982. Thermal condition of Surtsey. Surtsey Research Progress Report 9, 102-110.

Gailler, L. \& J. Kauahikaua, 2017, Monitoring the cooling of the 1959 Kilauea Iki lava lake using surface magnetic measurements. Bulletin of Volcanology 79.

DOI 10.1007/s00445-017-1119-7

Iceland Survey Department, 1965, Map of Surtsey volcano, October 23, 1964. Surtsey Research Progress Report 1, 4.

Jackson, M. D., 2020. Petrographic and material observations of basaltic lapilli tuff, 1979 and 2017 Surtsey drill cores, Iceland. Surtsey Research, Surtsey Research 14, 47-62.

Jackson, M. D., M. T. Gudmundsson, T. B. Weisenberger, J. M. Rhodes, A, Stefánsson, B. I. Kleine, P. C. Lippert, J. M. Marquardt, H. I. Reynolds, J. Kück, V. Th. Marteinsson, P. Vannier, W. Bach, A. Barich, P. Bergsten, J. G. Bryce, P. Cappelletti, S. Couper, M. F. Fahnestock, C. F. Gorny, C. Grimaldi, M. Groh, Á. Gudmundsson, Á. Th. Gunnlaugsson, C. Hamlin, Th. Högnadóttir, K. Jónasson, S. S. Jónsson, S. L. Jørgensen, A. M. Klonowski, B. Marshall, E. Massey, J. McPhie, J. G. Moore, E. S. Ólafsson, S. L. Onstad, V. Perez,
S. Prause, S. P. Snorrason, A. Türke, J. D. L. White \& B. Zimanowski, 2019a, SUSTAIN drilling at Surtsey volcano, Iceland, tracks hydrothermal and microbiological interactions in basalt 50 years after eruption, Scientific Drilling, 25, 35-46, DOI: https://doi.org/10.5194/sd-25-35-2019.

Jackson, M. D., S. Couper, C. V. Stan, M. Ivarsson, M. Czabaj, N. Tamura, D. Parkinson, L. M. Miyagi \& J. G. Moore, 2019 b. Authigenic mineral texture in submarine 1979 basalt drill core, Surtsey volcano, Iceland. Geochemistry, Geophysics, Geosystems 20 (7).

DOI: https://doi.org/10.1029/2019GC008304.

Jakobsson, S. P., 1972. On the consolidation and palagonitization of the tephra of the Surtsey volcanic Island, Iceland: Surtsey Research Progress Report 6, 121-128.

Jakobsson, S.P., 1978. Environmental factors controlling the palagonitization of the Surtsey tephra, Iceland. Geological Society of Denmark Bulletin 27, Special Issue, 91-105.

Jakobsson, S. P. \& J. G. Moore, 1982a. Introduction to the Surtsey Research Drilling Project of 1979. Special Issue of Surtsey Research Progress Report 9, I-II.

Jakobsson, S. P. \& J. G. Moore, 1982b. The Surtsey Research Drilling Project of 1979. Surtsey Research Progress Report 9, 76-93.

Jakobsson, S. P. \& J. G. Moore, 1986. Hydrothermal minerals and alteration rates of Surtsey volcano, Iceland. Geological Society of America Bulletin 97[5], 648-659.

Jakobsson, S. P. \& J. G. Moore, 2000. Geological monitoring of Surtsey, Iceland, 1967-1997. Surtsey Research 11, 99-108.

Jakobsson, S. P., J. G. Moore \& I. H. Thorseth, 2013. Palagonitization and lithification of the Surtsey tephra, Iceland. Proceedings of the Surtsey 50th Anniversary Conference, 1215 August 2013, Reykjavík, Iceland.

Lorenz. V., 1974a. Vesiculated tuffs and associated features. Sedimentology 21, 273-291.

Lorenz, V., 1974b. Study of the Surtsey tephra deposits. Surtsey Research Progress Report 7, 72-79.

Lorenz, V., 1986. On the growth of maars and diatremes and its relevance to the formation of tuff rings. Bulletin of Volcanology 48, 265-274.

McPhie, J., J. D. L. White, C. Gorny, M. D. Jackson, M. T. Gudmundsson \& S. Couper, 2020. Lithofacies from the 19631967 Surtsey eruption in SUSTAIN drill cores SE-2a, SE-2b and SE-03. Surtsey Research 14, 19-32.

Moore, J. G., 1982. Tidal and leveling measurements on Surtsey, July-August, 1979. Surtsey Research Progress Report 9, 98-101.

Moore, J. G., 1985. Structure and eruptive mechanism at Surtsey Volcano, Iceland. Geological Magazine 122, 649-661.

Norrman, J. O., 1970. Trends of post volcanic development of Surtsey Island. Progress on geomorphological activities in 1968. Surtsey Research Progress Report 5, 95-112. 
Ólafsson, M. \& S. P. Jakobsson, 2009. Chemical composition of hydrothermal water and water-rock interactions on Surtsey volcanic island, a preliminary report. Surtsey Research 12, 29-38.

Peck, D.L., M.S. Hamilton \& H.R. Shaw, 1977. Numerical analysis of lava lake cooling, Part II, application in Alai Lava Lake, Hawaii: American Journal of Science, 277, 415-437.

Sheridan, F. F., 1972. Textural analysis of Surtsey tephra, a preliminary report. Surtsey Research Progress Report, 6, 150 151.

Sigurgeirsson, T., 1965. Some geophysical studies in Surtsey in 1964. Surtsey Research Progress Report 1, 61-57.

Sigurgeirsson, T., 1974. Final report on geomagnetic measurements on Surtsey. Surtsey Research Progress Report VII, 91-84.

Thórarinsson, S., 1965. The Surtsey eruption, course of events and the development of the new island. Surtsey Research Progress Report 1, 52-59.

Thórarinsson, S., 1967. Surtsey, The New Island in the North Atlantic. The Viking Press, New York, 54 p.

Thórdarson, Th., 2000. Physical volcanology of lava flows on Surtsey, Iceland: a preliminary report. Surtsey Research 11, $109-126$.

Tryggvason, E., 1972, Precision levelling in Surtsey: Surtsey Research Progress Report VI, 158-162.

Weisenberger, T. B., M. T. Gudmundsson, M. D. Jackson, C. F. Gorny, A. Türke, B. I. Kleine, B. Marshall, S. L. Jørgensen, V. Th. Marteinsson, A. Stefánsson, J. D. L. White, A. Barich, P. Bergsten, J. G. Bryce, S. Couper, M. F. Fahnestock, H. Franzson, C. Grimaldi, M. Groh, Á. Gudmundsson, Á. Th. Gunnlaugsson, C. Hamelin, Th. Högnadóttir, K. Jónasson, S. S. Jónsson, A. Klonowski, J. Kück, R. L. Magnússon, E. Massey, J. McPhie, E. S. Ólafsson, S. L. Onstad, S. Prause, V. Perez, Velveth, J. M. Rhodes, S. P. Snorrason, 2019.Operational Report for the 2017 Surtsey Underwater volcanic System for Thermophiles, Alteration processes and INnovative concretes (SUSTAIN) drilling project at Surtsey Volcano, Iceland: GFZ German Research Centre for Geosciences.

DOI: http://doi.org/10.2312/ICDP.5059.001 